\title{
MARITIME CLUSTERS PRODUCTIVITY AND COMPETITIVENESS EVALUATION METHODS: SYSTEMATIC APPROACH
}

\begin{abstract}
Many scientists underline the importance of the clusters as agglomerated industries, working for the same purpose with joined resources and potential. This article analyses the basic assumptions which turn organizations to be clustered: the Productivity and the Competitiveness. For the evaluation of those assumptions in Maritime Clusters, many of the methods practically are applied without systematic approach - some are focused to the port efficiency, others provide quantity of resources growth dynamics, infrastructure parameters or even explain productivity and competitiveness as the same assumption. This article presents the analysis of Maritime Clusters' Productivity and Competitiveness evaluation methods in systematic approach, providing the analysis on the mostly-used variables and parameters of the evaluation the assumptions to be examined.
\end{abstract}

Key words: clusters, competitiveness, evaluation methods, productivity

\section{Introduction}

Fostering Maritime clusters is a way to enhance the competitiveness of regions and industry agglomerations, stimulate innovation, find ways to conserve and share resources, reduce business costs, and create sustainable employment in regions. The theory and practice of maritime cluster development effects and impacts to competitiveness and productivity is relatively new, but shows considerable efforts in helping to make the development of economies in the region more sustainable.

Summarizing many of the different scientists presented assumptions of Maritime clusters, two basic ones are analysed in this paper: the Productivity

Rasa Viederytė, Msc, Development Department Manager, Klaipeda University, Klaipeda, Lithuania, e-mail: rasa.viederyte@ku.It

** Loreta Dikšaite, Research board member, University of La Laguna, La Laguna, Spain, e-mail: loreta.diksaite.25@ull.edu.es 
and the Competitiveness. The Productivity is defined and presented from internal subject and capacity point of view; the Competitiveness is more linked to be presented from external variables and factors entire. Both of them are widely used in many of studies and reports, while calculating impacts and effects, capacities and potential, investments and innovations environment. The systematic approach of productivity and competitiveness evaluation may increase more objective and wider, more inclusive application of evaluation methods to be used and results to be obtained by following those techniques.

The main goal of this article - to analyze the Maritime Clusters' Productivity and Competitiveness evaluation methods in systematic approach: define statistically significant variables, which lead us to apply appropriate evaluation method for the assumptions to be examined.

Methods to be used: qualitative analysis of provided technique, scientific literature analysis and synthesis, analysis of statistical evaluation programs parameters.

\section{Productivity evaluation methodology}

The standard notion of productivity in maritime cluster refers to the productive efficiency of a given workforce that is labor productivity, measured in terms of output per input of labor (Gardiner, P. et al, 2004). Productivity analysis is relatively simple if there is only one type of input to produce one type of output (Coelli, 2005). In this case it is simply the ratio of output and input which makes it easy to compare companies as well as sectors (clusters) one to each other. However, in reality, various inputs are used to produce various outputs. In such cases, partial productivity is measured, e.g. output per worker, output per working hour, etc. Though these ratios are very limited and might be misleading. Thus, more elaborated analysis of productivity is necessary.

\subsection{Total or partial factor productivity}

Productivity analysis is very flexible, depending on the objectives either total factor (multifactor) or partial productivity can be estimated. Total factor productivity is estimated including various types of input and is more appropriate to evaluate total productivity of cluster. Main inputs are capital and labour, however, material and energy are sometimes met in various studies of productivity. Partial productivity can be either capital or labour productivity, and then accordingly only one type of output is chosen, i.e. capital or labour (number of employees or number of working hours).

The easiest way to compare productivity of two enterprises in cluster is their profitability i.e. ratio of income and expenditure. One should be careful as prices 
here are essential (both input prices and output prices). There are cases when one company has an advantage to access cheaper inputs or to sell production at higher prices. Thus, it is recommended to eliminate the effect of prices using prices deflators.

\subsection{Productivity evaluation methods}

There are various methods to estimate productivity out of which there are four the most common ways to measure it.

First way to measure productivity is to compare production growth with output growth which is known as Hicks Moorsteen index.

$$
\mathrm{HM} \text { index }=\frac{(\text { production growth })}{\text { (input growth) }}=\frac{\text { (production quantity index) }}{\text { (index quantity index) }}
$$

Even though it is easy to estimate and interpret this index, yet the reasons of productivity growth are not easy to be identified. Productivity growth may be caused by technical change or by increase in efficiency.

Total factor productivity (TFP) can also be measured by profitability growth after regulating price changes (by price deflator):

$\mathrm{TFP}=$

$$
\frac{\left(\mathrm{R}_{\mathrm{R}} /\left(\mathrm{R}_{\mathrm{S}}\right) / \text { (production price index }\right)}{(\mathrm{Ct} / \mathrm{Cs}) /(\text { input price index })}
$$

Where $C_{i}$ is cost at time $i, R_{i}$ is revenue at time $i$. As the effect of price changes is eliminated, total factor productivity depends on technical change or technical, allocate and economies of scale efficiency.

One more way to measure productivity is known as Caves, Chsitensen, Diewert (CCD). Generally, their idea was to compare current production with maximum feasible production (using the same technology and production set). This index is calculated from output and production distance functions.

The last method is to measure all sources or productivity and its components i.e. technical change, efficiency change and return on scales separately. Afterwards all these values are summed in order to get total factor productivity. This method is explained more in detail by Balk (2001).

Malmquist index is well-known total factor productivity index. It measures TFP change between two time moments as a ratio of distance between two points of certain technology (Coelli, 2005). Technical change and efficiency change can be estimated separately by this index.

Thus, if the objective is to find the level of productivity or its change without necessity to identify the source one can use Hicks Moorsteen or Malmquist TFP 
indices. However, the later requires wide range of panel data. On the other hand, second method is more applicable in financial analysis.

\subsection{Productivity analysis appliance}

Productivity analysis often is used for measuring Maritime cluster companies input to general economic cluster result. There are two ways of maritime clusters choice of productivity analysis appliance: to evaluate sectorial productivity and to evaluate Firm-linked productivity.

\subsubsection{Sectorial productivity}

In the analysis of airline performance and productivity growth Barros and Couto (2013) calculate Luenberger and Malmquist indexes, where they use revenue per passenger per kilometre and revenue per ton of cargo as output variables and number of workers, operational costs and number of seats as input.

If technology is a set $\mathrm{T} \subseteq \mathrm{R}_{+}^{\mathrm{N}} \times \mathrm{R}_{+}^{\mathrm{M}}$,

then $T_{t}=\left\{\left(x_{t}, y_{t}\right): x_{t}\right.$ canproduce $\left.y_{t}\right\}$, where $x_{t} \in R_{+}^{N}$ is input vector and

$y_{t} \in R_{+}^{M}$ is output vector at time t.Then directional distance function

is $D_{t}: R^{n+p} \times R^{n+p} \rightarrow R U\{-\infty\} \cup\{+\infty\}$, where direction is $g=(\mathrm{h}, \mathrm{k})$ from

which Luenberger productivity index can be calculated.

Fare et al (1994) analysed 17 OECD countries efficiency by Malmquist index. In his study production variable is Gross domestic product of a country while equity of all enterprises and work are considered as output. Every country is compared to the best practice productivity frontier that is created from the countries all around the World.

When Chang and Oxley (2009) evaluate the effect of geographical innovation to total factor productivity, the later is calculated for each enterprise, from values of which average sector's (cluster's) total productivity is derived. Total factor productivity is measured by this function:

$$
Q_{i}=F\left(X_{1 i}, X_{2 i}, X_{3 i}, X_{4 i}\right) \text { where }
$$

$X_{i j}$ with $j=(1,2,3,4)$ are accordingly capital, labour, energy and materials. Later functional form needs to be chosen, in practice, trans log function as being the most flexible is the most common.

However, Martin et al (2011) apply Cobb-Douglas TFP function to industrial (it can be applied also to maritime) clusters of France and use general method of moments instead of OLS to find coefficients.

There are a few studies of Cullinane et al (Cullinane et al. (2002), Cullinane ir Wang (2006), Cullinane ir Wang (2010) about the efficiency and productivity 
of Asian container terminals where Stochastic frontier analysis and Data Envelopment analysis were applied. According to the researchers containers throughput is the most important and the most common output variable in studies about container and port productivity. Cullinane et al (2002) describes throughput as the number of containers moving through the territory of quay or it can be expressed in monetary terms as the revenue related to this process. Whereas, as input variables length of terminal, area of terminal, equipment that is necessary to move cargo (various types of cranes) is chosen. In their later studies as the most significant variables were used terminal length, area, gantry cranes and straddle cranes. Moreover, according to Cullinane et al (2005), including the number the most important (and necessary) equipment moving the biggest amount of cargo, that in container (or port) sector are yard gantry cranes and straddle carriers handle cranes, is sufficient for the analysis.

Díaz-Hernández et al (2008) with reference to Cullinane analysed ports of Spain during the reform and declared that productivity function comprise of three variables: containerized general cargo, no containerized general cargo, solid bulk and other two types of variables that are working hours of cranes and workers.

\subsubsection{Firm-level productivity}

Some authors (Giuliani et al, 2013; Hulten, 2001; Syverson, 2011) use productivity as outcome variable of measuring efficiency in Firm-level. Despite of Firm-level productivity variable, as part of efficiency measuring, there are also outcome indicators groups to be involved: Export-related indicators, Innovationrelated indicators and Employment-related indicators. On this point of view, Firm-level productivity covers those indicators: Annual value of production, Number of employees (number of permanent and temporary employees), Materials (value of materials used in the production process), Capital stock (net book value of machinery and equipment) and Labor cost.

Measuring productivity is not simple task. There are several measures relating to the productivity of companies, two of which are to consider the productivity of one input, such as labor productivity, or to consider the productivity of all inputs, such as total factor productivity. With regard to total factor productivity, all matters related to the measurement of input and output, are present and change in output cannot be explained as change in input (Giuliani et al, 2013). Several methods exist to obtain total factor productivity, all of which hint to varying assumptions relating to the production process and the degree to which the market is competitive. This suggests that each method has strong and weak parts.

When the interest is in the productivity or maritime industry, cluster or of a geographical region, it is also important to study the reallocation of resources between firms. If more productive maritime companies gain market share, there 
is as improvement of the aggregate level of productivity, since the aggregate level of productivity over headed average of the productivity of each unit. The weight is the market share, but in some cases, the employment share also is used as the weight. So to gain the effect at the aggregate level, it is necessary to evaluate its effect on the productivity and growth-measured by sales or employment - of each firm and on the firm's decision to enter or exit the market (Van Biesebroeck, 2007). There are several variables that are related to productivity: value of exports, $\mathrm{R} \& \mathrm{D}$ expenditures, technology adoption and innovation.

\section{Essentials of competitiveness analysis methodology}

A cluster is competitive if it is able to generate synergetic advantages through innovation and the efficient use of resources across company and industry borders. Competitiveness on the cluster level can be measured by looking at the market shares, the growth of value added and the gross production of the cluster (Viitanen et al, 2003).

Maritime clusters enhance competitiveness of economies in many ways: by development of networks, by development of innovation systems and innovative milleaus, by investment Spin-Offs from research and development outcomes and others.

Competitiveness analysis as any other analysis can be performed from various points that depend on nothing but prior objectives of the every study. There is a vast majority of methods, models and indices that might be applied, as well as intersect with each other and be supplemented. Also scientific literature covers the competitiveness meaning in majority of different meanings and variables; competitiveness analysis includes most of the elements, analysed in productivity chapter.

According to macroeconomic theory, revealed comparative advantage uncovers the advantage of international trade of one country against another.

The most frequent methods of competitiveness analysis are Porter's Diamond model and Analytical Hierarchy Process model that may follow after other methods such as experts survey according to which results the most important factors are anticipated.

Moreover, corporate finance is not less important issue in competitiveness analysis. Indices such as return on investment (ROI), return on assets (ROA) are worth to be evaluated and compared. Apart from these value added growth and market share are common in this type of studies.

Herciu (2013) analysis of International Competitiveness of Romania comprise of two parts. Firstly comparative advantages and disadvantages were identified and evaluated by the model of Porter's Diamond and later in the analysis revealed comparative advantage was estimated.

Comparative advantage is found by the following formula: 
Maritime clusters productivity and competitiveness evaluation methods... 221

$\mathrm{X}_{\mathrm{ij}}$ - export of good $\mathrm{j}$ from country $\mathrm{i}$,

$\mathrm{RCA}_{\mathrm{ij}}=\left(\mathrm{X}_{\mathrm{ij}} / \mathrm{X}_{\mathrm{wj}}\right) /\left(\mathrm{X}_{\mathrm{i}} / \mathrm{X}_{\mathrm{w}}\right)$, where:

$\mathrm{X}_{\mathrm{wj}}$ - export of good $\mathrm{j}$ worldwide,

$\mathrm{X}_{\mathrm{i}}$ - total export from country $\mathrm{i}$,

$\mathrm{X}_{\mathrm{w}}$ - world export.

The range of value is from minus infinity to plus infinity. Positive value means comparative advantage, while negative value has a meaning of comparative disadvantage.

J. Tongzon, W. Heng (2005) evaluated port competitiveness by the index, where total throughput is chosen as a proxy and the significance of all the determinants is estimated by running a regression. According to their results adaptability of a port to changing customer needs is the crucial factor in competitiveness of a port. Other less important determinants are investment in marketing and Port selection preferences of carriers and shippers.

Port competitiveness analysis and competitiveness strategy development can also be evaluated by less common multi criteria decision making methods as PROMETHEE, Technique for Order Performance by Similarity to Ideal Solution (TOPSIS), Gray Relation Analysis and Hierarchical Fuzzy process (Lirn et al., 2003, 2004; Ugboma et al., 2006; Castillo-Manzano et al., 2009; Guy ir Urli, 2006; Celik et al., 2009; Teng et al., 2004; Huang et al., 2003; Yeo and Song, 2006) (Lee Lam and Zhang).

\subsection{M.Porter "Diamond" model adoption}

Porter in 1990 created a model that is called Porter's Diamond that later was modified by various scientists (Trabold (1995), Krugman (1996), Aiginger (1998), Mitschke (2008), etc.). According to the model, in microeconomic level competitive advantage is determined by factor conditions (natural conditions such as location and climate and human created conditions - telecommunications, energy maintenance, high quality universities, laboratories, quality of financial services, quality of the whole infrastructure, etc.), demand conditions (that include size of the market, trade taxes, $R \& D$ investments, etc.) and related industries, where the quality and the quantity of the providers play the main role). Beside microeconomic conditions there are macroeconomic factors that are not less important as the later ones, these are government and unpredicted events. When all these conditions are put together the way they intersect one with each other created the nature of international competitiveness (Sirikrai and Tang, 2006).

Not only researchers, but also Cities Communities for equitable development adopt Porter's diamond model for the evaluation of relative competitiveness (Choe et al, 2011). Analysis use cardinal or alphabetic scale or symbols ("+"or "“") to score the strength of five conditions. Besides, chance is a random occur- 
rence, so it is not generally included in the analysis. Total amount of elements under the five conditions are analyzed for each cluster using a semi-qualitative scoring method. The relative competitiveness of each condition is measured on a numeric scale of 0-5. A Delphi technique is used in scoring (Bordecki, 1984). The scores recorded by the assessors are averaged then discussed and adjusted to arrive at the final score for the industry cluster.

The next step of the analysis involves what are the gaps in the competitiveness conditions and elements of a cluster. Where are the significant differences, the need of action to strengthen the weak elements and improve a cluster's overall competitiveness and economic performance is indicated (Table 1).

Table 1: Sample analysis of Competitive Elements of Clusters using Porter's Diamond Model (Choe et al, 2011, p. 107)

\begin{tabular}{|c|c|c|c|}
\hline Competitive element & $\begin{array}{l}\text { Current } \\
\text { status }\end{array}$ & $\begin{array}{l}\text { Requirements } \\
\text { for future } \\
\text { Competitiveness }\end{array}$ & Actions \\
\hline \multicolumn{4}{|l|}{ Markets } \\
\hline Expanding domestic and local markets & 3 & 1 & Market intelligence \\
\hline Expanding export markets & 2 & 4 & $\begin{array}{l}\text { Collaborative } \\
\text { marketing }\end{array}$ \\
\hline \multicolumn{4}{|l|}{ New products } \\
\hline $\begin{array}{l}\text { Demand expansion capacity for } \\
\text { new products }\end{array}$ & 2 & 4 & New technologies \\
\hline $\begin{array}{l}\text { Responsiveness to change and } \\
\text { innovativeness }\end{array}$ & 2 & 3 & Change management \\
\hline
\end{tabular}

The analysis of competitiveness deficiency gaps provides an indication of the strengths and weaknesses of the five factors affecting the competitiveness of industry clusters as well as the potential threads and opportunities facing the development of an industry cluster. Projects and programs that should be considered in an action plan to strengthen the industry cluster and promote industry cluster development can be identified on this way.

\subsection{Essence of the Analytical Hierarchy Model}

Analytical Hierarchy Model (AHP) that was found by Thomas L. Saaty in 1970's and applied for many years in mathematical decision making, nowadays may help to identity and evaluate, which indicators of organizational behaviour and to what level are important when competitiveness of a sector is being analysed (Sirikrai, Tang, 2006). Moreover, the model that enables to measure the 
importance of factors helping organizations to perform better compose of three steps:

1) organizing a problem to a hierarchical structure;

2) prioritizing elements in the model;

3) making the final decision according to the results.

In the study of competitiveness of ports Yuen et al (2012) apply the AHP model that consists of three levels. The objective level is port competitiveness, that is succeed by the second level - determinants of port competitiveness (such as port location, port expenditure, port equipment, operators, information systems, communication services in port territory, customs and government regulation). The factors were carefully selected from antecedents. The third level is made of sub factors that expand in each category of the later. In order to select the crucial factors, authors used Government specialist and Decision maker's surveys. All factors and sub factors were weighted in accordance to the results of surveys.

\subsection{Financial and non-financial indicators importance}

Financial indicators reflect the financial management part of the unit. However, the overall performance of one depends on many other factors that are necessary to be evaluated.

Benito et al (2003) analyse international competitiveness of Norwegian maritime cluster through revealed comparative advantage and OECD market share as well as sales, creation of net value, return on assets, capital return, export of sales and services.

According to Viitanen (2003) cluster is competitive if it is able to generate advantage of synergy through innovations and effective use of recourses. Market share, value added growth and total production of a cluster are its determinants. The researcher also applies Porter's Diamond model that was explained above.

Sirikrai and Tang (2006) apart from the return on assets consider return on investments as the indicators of competitiveness. They suggest to pay attention to other, non-financial indicators: satisfaction of clients, market share, sales and sales growth. When one evaluates financial as well as non-financial indicators, wider analysis is accomplished.

\section{Conclusions}

Although there is considerable debate amongst academics for the precise definition of productivity, there can be agreed that productivity represents ones of its most important competition measure elements, which may be presented by 
using not just financial, but also non-financial indicators, marketing and strategic management techniques.

In this paper, we have investigated some of the conceptual and measurement problems that arise in measuring assumptions of maritime cluster productivity and competitiveness: Firm-related and industry based Productivity analysis methodology differ; Export, Foreign investment, Innovations and Employment are the variables can be met in both assumptions; many of input and output variables are used accordingly to the developed models, which also are flexibly modified and adopted by the authors.

Total factor productivity "traditional" inputs are capital and labour, however, material and energy are sometimes met in various studies of productivity. Partial productivity covers capital or labour productivity, and then, accordingly to previously chosen variable - number of employees or number of working hours. Hicks Moorsteen index, Luenberger and Malmquist indexes are mostly used as Productivity measurement tools; Total factor productivity is mostly universal tool for Productivity measurement in cluster and Firm-based levels.

Although many of criticism follows with the classical models of competitiveness evaluation, the Porter "Diamond" model and Essence of the Analytical Hierarchy Model still remain as mostly practically used ones.

\section{Literature}

- Balk, B.M. (2001). Scale Efficiency and Productivity Change. Journal of Productivity Analysis, (15) (p. 159 - 183).

- Barros, C.P., Couto, E. (2013). Productivity Analysis of European Airlines 2000-2011. Journal of Air Transport Management (31) (p. 11-13).

- Benito, G., Berger, E., de la Forest, M. \& Shum, J. (2003). A cluster analysis of the maritime sector in Norway. International Journal of Transport Management 1 (4) (p. 203-215).

- Bordecki, M.J. (1984). A Delphi approach. New York: New York University.

- Chang, C.-L., Oxley, L. (2009). Industrial Agglomeration, Geographic Innovation and Total Factor Productivity: The Case of Taiwan. Mathematics and Computers in Simulation (79(9)) (p. 2787-2796).

- Choe, K., Roberts, B. (2011). Competitive Cities in the $21^{\text {st }}$ Century: ClusterBased Local Economic Development. Philippines: Asian Development Bank.

- Coelli, T.J., Rao, D.S.P., O’Donnell, C.J., G.E. Battese (2005). An Introduction to Efficiency and Productivity Analysis, 2nd Edition. New York: Springer.

- Cullinane, K. P. B., Ji, P., Wang, T.F. (2005a). The relationship between privatization and DEA estimates of efficiency in the container port industry. Journal of Economics and Business (57. 5) (p. 433-462). 
- Cullinane, K. P. B., Song D. W. (2002). A Stochastic Frontier Model of the Productive Efficiency of Korean Container Terminals. Applied Economics (35(3)) (p. 251-267).

- Cullinane, K. P. B., Wang, T.F. (2006). The efficiency of European container terminals: a cross-sectional data envelopment analysis. International Journal of Logistics Research and Applications (9,1) (p. 19-31).

- Cullinane, K., Wang T. F. (2010) The efficiency analysis of container port production using DEA panel data approaches. OR Spectrum (32(3)) (p. 717-738).

- Díaz-Hernández, J., Martínez-Budría, E., Jara-Diaz, S. 2008. Parametric estimation of inefficiency in cargo handling in Spanish ports. Journal of Productivity Analysis (30, 3) (p. 223-232).

- $\quad$ Fare R., Grosskopf S., Norris M., Zhang, Z. (1994). Productivity Growth, Technical Progress, and Efficiency Change in Industrialized Countries. The American Economic Review (84, 1) (p. 66-83).

- Gardiner, B., Martin, R., Tyler, P. (2004). Competitiveness, Productivity and Economic Growth across the European Regions. ERSA conference papers from European Regional Science Association.

- Giuliani, E., Maffioli, A., Pacheco, M. et al. (2013). Evaluating the Impact of Cluster Development Programs. Inter-American Development Bank, Technical note Nb. IDB-TN-551.

- Herciu, M. (2013). Measuring International Competitiveness of Romania by Using Porter's Diamond and Revealed Comparative Advantage. Procedia Economics and Finance (6) (p. 273 - 279).

- Hulten, C. (2001). Total Factor Productivity: A Short Biography. New Developments in Productivity Analysis.Chicago:University of Chicago Press.

- Lee Lam J. S., Zhang, W. Analysis on Development Interplay between Port and Maritime Cluster.

- Martin P., Mayer T., Mayneris, F. (2011). Public Support to Clusters A Firm Level Study of French "Local Productive Systems". Regional Science and Urban Economics (41) (p. 108-123).

- Sirikrai, S. B., Tang J. C. S. (2006). Industrial competitiveness analysis: Using the Analytic Hierarchy Process. Journal of High Technology Management Research (17) (p. 71-83).

- Syverson, C. (2011). What Determines Productivity? Journal of Economic Literature. 49(2), 326-365.

- Tongzon, J., Heng, W. (2005). Port Privatization, Efficiency and Competitiveness: Some Empirical Evidence from Container Ports (Terminals). Transportation Research. Part A. (39) (p. 405-424).

- Van Biesebroeck, J. (2007). Robustness of Productivity Estimates. The Journal of Industrial Economics, 55(3), 529-569. 
- Viitanen, M., Karvonen, T., Vaiste, J., Hernesniemi, H. (2003). The Finnish Maritime Cluster. Technology Review, (145).

- Yuen, C.-l. A., Zhang, A., Cheung, W. (2012). Port Competitiveness From the Users' Perspective: An Analysis of Major Container Ports in China And its Neighboring Countries. Research in Transportation Economics, (35(1)) (p. 34-40).

Paper received: May $15^{\text {th }}, 2014$

Approved for publication: June $1^{\text {st }}, 2014$
Rad primljen: 15. maj 2014. Odobren za štampu: 1. jun 2014. 
Ms Rasa Viederyté,

Univerzitet u Klaipedi , Litvanija

Loreta Dikšaitè,

Univerzitet u La Laguni, Španija

\title{
POMORSKE SKUPINE PRODUKTIVNOSTI I KONKURENTNOSTI METODE PROCENE: SISTEMATSKI PRISTUP
}

\begin{abstract}
S a ž e $\mathbf{t}$ a $k$
Rad analizira osnovne pretpostavke koje pretvaraju organizacije u skupine: produktivnost i konkurentnost. Za procenu ovih pretpostavki među pomorskim skupinama, primenjuju se mnoge metode bez sistematskog pristupa - neke su fokusirane na efikasnost luka, dok druge metode obezbeđuju količinu rasta resorsne dinamike, infrastruktualne parametre i objašnjavaju produktivnost i konkurentnost $\mathrm{u}$ istoj pretpostavki. Ovaj rad predstavlja analizu pomorske skupine, njene produktivnosti i konkurentnosti, metode procene u sistematskim pristupima, pružajući analizu najčešće korišćenih varijabla i parametara pri proceni pretpostavki koje trebaju biti ispitane.
\end{abstract}

Ključne reči: skupine, konkurentnost, metoda procene, produktivnost 
